\title{
Al-Ghazali dan Perilaku Pasar: Perpesktif Etika Bisnis dalam Kitab Ihya Ulum ad-Din
}

\author{
Sarini Syarifuddin ${ }^{1)}$, Muhammad Ikhwan Saputra ${ }^{2)}$ \\ ${ }^{1}$ Fakultas Ekonomi dan Bisnis Islam, Universitas Islam Negeri Sunan Kalijaga \\ ${ }^{2}$ Fakultas Ekonomi dan Bisnis Islam, Universitas Islam Negeri Ar-raniry Banda Aceh \\ *Email korespondensi: Sariniayunda280215@gmail.com
}

\begin{abstract}
One of the leading moeslem economists named al-Ghazali puts more concerns about the problems of economic activities which is related to market behaviour. Ihya ulum al-Din is one of the most popular his work in economics. Al-Ghazali Pointed out that money hoarding, foreign exchange market and riba are market's elements. This research was conducted through library research and secondary data gained from books, articles, newspapers, internet and other sources that has correlation to this topic. In contemporary, al-ghazali's Business ethics have mismatch one another. In this era, money hoarding is still happening in a society, a majority of them are waiting for higher exchange rate and Dollars become shortage. Additional in a transaction between a producer and consumer is claimed as riba in Islam. Foreign rate's fluctuation in a country can cause unhealthy competition that can lead to high risk speculation.
\end{abstract}

Keywords : Al-Ghazali, Business, Ethics, Market, Behaviour.

Saran sitasi: Syarifuddin, S., \& Saputra, M. I. (2020). Al-Ghazali dan Perilaku Pasar: Perpesktif Etika Bisnis dalam Kitab Ihya Ulum ad-Din. Jurnal Ilmiah Ekonomi Islam, 6(03), 501-507. doi:http://dx.doi.org/10.29040/jiei.v6i3.1312

DOI: http://dx.doi.org/10.29040/jiei.v6i3.1312

\section{PENDAHULUAN}

Islam bukanlah sebuah agama yang berarti dianut oleh manusia, tetapi hal ini dapat dikatakan sebagai pedoman hidup bagi para penganutnya. Di mana hal tersebut merupakan bagian dalam kehidupan manusia yang telah diatur menurut hukum Islam. Pada dasarnya, filosofi Islam mengajarkan beretika dalam berbisnis dan melahirkan konsep penting dalam bisnis lainnya. Terutama berupa sikap atau perilaku dari bisnis Islam itu sendiri yang menggunakan konsep tauhid.

Ekonomi Islam, dalam kegiatan ekonomi yang berupa usaha dan perilaku tidak harus di pandang sebagai dua hal yang bertentangan dalam Islam, sebab usaha dalam perilaku pasar dapat diartikan sebagai simbol dari kegiatan dunia yang di anggap dari bagian yang integral untuk investasi akhirat. Kegiatan ini di artikan, jika sebuah bentuk usaha dalam melakukan upaya investasi akhirat nanti, maka sebuah kegiatan usaha harus dengan sendirinya berjalan dengan sesuai ketetapan moral yang berlandaskan keimanan dengan akhirat. Dalam hal ini, Islam sendiri dapat dikatakan suatu bisnis dalam urusan dunia tidak dibatasi, sehingga dapat menggambarkan seluruh kegiatan dibisniskan (diniatkan dengan ibadah) di dunia, untuk mendapatkan keuntungan atau pahala di akhirat. Dalam hal ini, suatu kegiatan usaha dalam Islam tidak orientasinya semat-mata terhadap dunia saja. Akan tetapi kegiatan usaha harus mempunyai visi terhadap akhirat nanti. Dengan kata lain perilaku dalam usaha menjadi satu hal penting dalam kegiatan ekonomi Islam.

Islam menawarkan konsep etika atau perilaku dalam bisnis sebagai pendorong bangkitnya perputaran roda ekonomi Islam. Sehingga, dasar dari filosofi yang menjadi suatu catatan yang penting bagi pembisnis dalam etika usah yang dijalankan dengan konsep membangun hubungan manusia antara manusia, serta hubungan manusia dengan tuhannya. Sehingga aspek-aspek perilaku ekonomi dalam etika bisnis yang perlu dikembangkan meliputi tujuan hidup 
cara memandang dan menganalisis prinsip-prinsip dan etika ekonomi dalam Islam.

Bisnis atau perdagangan merupakan suatu kegiatan manusia yang terpenting. Bisnis atau perdagangan di perlukan di dalamnya tidak ada manusia hidup sempurna dan sanggup menyediakan kebutuhan atau keperluan tanpa memerlukan orang lain. Sehingga dapat dikatakan manusia saling memerlukan dan membutuhkan pertolongan antara sesama. Islam mengajarkan untuk mencari rezeki yang halal,berkah dengan cara yang baik kepada seluruh umatnya untuk kehidupan mereka.

\section{Nabi telah bersabda:}

"Pedagang yang jujur akan di himpunkan pada hari kiamat bersama-sama dengan kaum shiddiqin dan para syuhada."

Etika bisnis al-Ghazali dalam konteks kekinian terdapat banyak ketidaksesuaian satu dengan lainnya. Aktivitas bisnis dewasa ini, lebih kepada keuntungan semata. Sehingga etika dalam berbisnis masih jauh dari apa yang di sampaikan al-Ghazali etika bisnis harus disatukan, semata-mata untuk bekal yang lebih kekal Islam sendiri sebagai agama yang komprehensif memiliki petunjuk yang sempurna (Al-Quran) dan mengandung prinsip-prinsip sebagai pedoman yang fundamental dalam urusan etika dalam berbisnis. Kaidah-kaidah yang terkandung dalam Al-Quran diinterpretasikan serta dikemas sangat konkret dan mudah dipahami oleh banyak orang dan ulama-ulama terdahulu sebagai peletak teori. Di antara ulama yang menekuni dan membahas masalah etika dan bisnis dalam Islam adalah ulama yang terkenal akan filsafat dan tasawufnya yaitu imam Al-Ghazali.

Tokoh ekonom Muslim salah satunya yang bernama al-Ghazali sangat memperhatikan tentang permasalahan dalam kegiatan ekonomi yang terkait tentang perilaku pasar. Dalam ekonomi dapat ditemukan karyanya yang sangat fenomenal Ihya ulum $A L$, imam Al-Ghazali mengungkapkan elemenelemen pasar salah satunya tentang penimbunan uang, jual beli mata uang dan riba.

\section{METODE PENELITIAN}

Metode penelitian yang digunakan dalam penelitian ini peneliti menggunakan penelitian Library Research. Berupa data sekunder yang diperoleh atau yang di dapatkan dengan cara mengkaji buku-buku, artikel, surat kabar atau internet dan sumber yang berkaitan .
Sehingga, penulis memaparkan pembahasan utama seputar etika bisnis dalam ekonomi Islam dalam perilaku pasar serta kontribusi pemikiran ekonomi dalam Islam imam Al-Ghazali yang diterapkan dalam konteks sekarang. Oleh karena itu peneliti akan menjelaskan etika bisnis Al-Ghazali dan perilaku pasar: perspektif etika bisnis dalam kitab Ihya Ulum ad-Din.

\section{HASIL DAN PEMBAHASAN}

\subsection{Hasil Penelitian}

\section{Kontribusi Pemikiran Al-Ghazali dalam Pengembangan Etika Bisnis Islam Dalam Konteks Kekinian.}

Permasalahan dari kegiatan bisnis dalam transaksi ekonomi yang terjadi saat ini baik secara entitas maupun aktivitas di dalamnya terstruktur sendiri, bisnis harus berjalan sebagaimana proses dapat menjadi manusia sebagai individu atau masyarakat untuk mencari keuntungan dalam memenuhi kebutuhan dan keinginan hidupnya dari kegiatan bisnis.

Apabila kita kaitkan teori pemikiran al-Ghazali dengan etika perilaku pasar masa kini maka terdapat banyak ketimpangan atau ketidaksesuaian dengan satu dan lainnya. Dewasa ini, aktivitas bisnis lebih berorientasi pada keuntungan semata, hal tersebut masih jauh dari teori pemikiran al-Ghazali etika dalam perilaku pasar harus disatukan sesuai dengan aturan syariat Islam. Karena apa yang kita lakukan faktor keuntungan semata.

\section{a. penimbunan uang}

Dalam hal ini, sebagaimana fakta yang terjadi dewasa sekarang ini, bahwa perilaku pasar al-Ghazali tentang penimbunan uang dalam masyarakat kini masih terjadi dengan istilah lain spekulasi. Oleh karena itu ketika terjadi praktik penimbun dolar untuk spekulasi, sehingga masyarakat terus menunggu kurs yang lebih tinggi, maka dolar menjadi langka.

Akibatnya orang-orang yang ingin pergi haji harus membeli dolar dengan kurs yang lebih tinggi. Dalam konteks sekarang ini penimbunan uang tidak hanya merugikan masyarakat atau kepentingan umum secara finansial. Tetapi juga berpotensi meninggalkan ibadah. Sehingga penimbunan uang merupakan tindakan yang sisi mudaratnya lebih besar di bandingkan dengan penimbunan barang biasa yang terjadi di masyarakat.

Oleh karena itu, penimbunan uang yang terjadi pada masa kini dapat mengakibatkan harga komoditas 
naik, maka implikasi dari penimbunan uang menjadi jauh lebih berbahaya. Secara logika hal ini dapat terjadi kadar kemudharatannya jauh lebih nyata. Sehingga dapat tidak menstabilisasikan perekonomian. Penimbunan uang dapat mempengaruhinya perekonomian karena uang yang disimpan dan ditahan tidak ikut serta dalam usahausaha produktif. dalam artian uang dapat di jadikan sebuah modal usaha dalam melakukan usaha yang produktif dalam inovasi baru dan kreatif dalam meningkatkan pertumbuhan perekonomian. Penimbunan uang dapat menyebabkan timbulnya peningkatan gejolak permintaan terhadap uang dalam perekonomian, sehingga dapat menyebabkan siklus perekonomian suatu negara terganggu.

\section{b. Problematika riba}

Pemikiran Al-Ghazali sangat sesuai dan amanat dalam hal problematika riba bahwa artian uang adalah uang, fungsi dari uang sebagai alat transaksi dalam kegiatan tukar menukar dalam aktivitas ekonomi dan sebagai alat penyimpan nilai dari uang. Sehingga uang tidak dapat berkembang biak.

Dalam problematika sekarang ini, yang dikatakan dengan riba setiap penambahan yang dilakukan dalam transaksi jual beli antara produsen maupun konsumen dalam perekonomian dikatakan dengan riba. Dalam perekonomian masyarakat, sudut pandang ekonomi dan etika riba meruntuhkan sendi-sendi kemanusiaan, pada akhirnya mencegah peningkatan perekonomian negara. Bunga yang signifikan memicu terjadinya inflasi dalam perekonomian negara, untuk membayar hutang dan meminjam harus menaikkan harga bunga yang dibayarkan dan terjadi di kalangan masyarakat dalam terhadap pasar sekarang ini. Hal ini membuat ketidakadilan dalam perekonomian dan menimbulkan krisis perekonomian dengan sistem ribawi.

\section{c. Jual beli mata uang}

Al-Ghazali telah melarang kegiatan jual beli mata uang, jika kegiatan jual beli mata uang diperbolehkan dalam kegiatan ekonomi maka hanya mereka saja atau golongan orang kaya sama saja dengan membiarkan orang lain melakukan praktik penimbunan uang dalam masyarakat. Dalam masa sekarang ini pemikiran perilaku pasar al-Ghazali tentang jual beli mata uang masih terjadi dengan istilah valas dalam perekonomian. Naik turun kurs mata uang dalam perekonomian negara, sehingga muncul persaingan yang tidak sehat antara pelaku bisnis sehingga timbulnya spekulasi yang mengakibatkan risiko tinggi. Sehingga tidak sedikit orang yang kaya mendadak dalam satu hari dan tidak sedikit orang yang mengalami bangkrut dalam kurun waktu yang sama.

Berdasarkan statistik perbankan Indonesia yang di liris Otoritas Jasa Keuangan (OJK) hingga akhir Juni 2019 nilai kredit valas yang sudah disalurkan tumbuh $6.62 \%$ secara year on year menjadi Rp801,55 triliun. Meski meningkat pertambahan nilai kredit valas per akhir Juni 2019 tidak sebesar yang terjadi sebelumnya.

Ketika terjadinya perbedaan tukar menukar nilai mata uang berbeda jenis. Terjadi nilai mata uang(kurs). Misalnya mata uang USD dengan mata uang Indonesia. Sehingga transaksi mata uang harus sama nilai nominalnya. Bahwa masyarakat agar tidak menukar uang mereka kecuali dalam keadaan kondisi darurat, misalnya ketika bepergian ke negara lain dan membutuhkan mata uang negara tujuan. Oleh karena itu valas merupakan suatu komoditas yang masih melemah sehingga harganya juga terpengaruh oleh perkembangan global ekonomi yang melambat akibat perang dagang.

\subsection{Pembahasan}

\section{Etika Perilaku Ekonomi Islam}

Kata Etika Secara Etimologi,Berasal dari Bahasa Yunani yaitu Kuno ethos yang berarti perilaku, cara berpikir, kebiasaan, adat, akhlak dan kebiasaan. Dalam bentuk jamak Ethos dapat berarti ta-etha yang artinya adat dan kebiasaan dalam kata inilah dapat dibentuk sebuah istilah kata etika yang dapat pakai oleh seorang filsuf besar Yunani. Sedangkan bisnis berasal dari kata Bahasa Inggris yang artinya perusahaan urusan atau usaha apabila dikaitkan dengan perusahaan, bisnis dapat dikatakan sebuah organisasi yang merupakan segala sesuatu menyediakan barang atau jasa maksud tujuan untuk mendapatkan keuntungan atau laba pada kegiatan ekonomi.

Oleh karena itu dapat kita temukan pasar Imam al-Ghazali berada pada teks al-Qur'an, al-Hadits, dan Atsar para Sahabat yang dijelaskan secara argumentatif dengan pendekatan akal maupun intuisi sehingga menghasilkan gagasan-gagasan etika yang religius sekaligus spiritual. Secara umum etika religius ini juga dikembangkan dalam perekonomian Islam modern. Dalam perekonomian modern, pengembangan etika religius ini berfungsi sebagai pembeda antara ekonomi Islam dengan ekonomi positif yang bertumpu pada etika rasional. 


\section{Jurnal Ilmiah Ekonomi Islam, 6(03), 2020, 504}

Dalam kitabnya Ihya ulum ad-Din al-Ghazali (2000) Berkata :

Tidaklah pantas bagi para penjual kegiatannya hanya memfokuskan pandangannya pada kegiatan dunia saja, sehingga dapat melupakan kegiatan akhirat. Jika demikian terjadi maka umurnya akan siasia. sebaiknya bagi yang berakal di anjurkan untuk memelihara dirinya dengan cara menjaga modalnya manusia dalam kehidupan ini merupakan agama dan bisnis dalam urusan ekonomi.

Dalam sebuah hadis disebutkan bahwa sesungguhnya Allah SWT menyukai orang mukmin yang bekerja. Dan telah disebutkan pula bahwa Nabi telah bersabda:

Artinya: Tidak pernah di wahyukan kepadaku, "kumpulkanlah harta dan jadilah pedagang", melainkan diwahyukan kepadaku, "Bertasbihlah dengan memuji tuhan mu dan jadilah orang-orang yang sujud, dan sembahlah tuanmu sampai datang keyakinan kepadamu."

Untuk mencapai target atau tujuan yang di inginkan dalam berbisnis, al-Ghazali membagi beberapa hal dalam etika bisnis untuk melakukan aktivitas ekonomi yang dijalankannya (alGhazali,2000) yaitu:

1. Dapat meluruskan niat. Artinya niat yang benar dalam kaidah yang suci dapat diartikan sebuah langkah utama dalam urusan berdagang. Menetapkan niat dengan cara berdagang sehingga mendapatkan hal yang halal dan berkah. Dengan kata lain berdagang terjauh dari tindakan mencari rezeki yang haram. Jika niat ini tertanam, hal ini merupakan satu ladang yang akan kita investasikan untuk akhirat nanti. Adapun keuntungan yang kita peroleh dari usaha adalah bonus yang diberikan di dunia.

2. melaksanakan fardhu kifayah artinya dalam urusan berdagang atau usaha maka niatkanlah suatu kegiatan dalam melaksanakan fardhu kifayah, maka setiap orang menjalankan kegiatannya secara konsisten dan benar.

3. Memperhatikan pasar akhirat, artinya Al-Ghazali berharap dapat menjalankan semua kegiatan usaha saat berinteraksi di pasar. Maka dapat mengingatkan dan menjalankan perintah Allah.

4. Terus berdzikir selama berada di pasar artinya dalam menjalankan urusan bisnis para pedagang dapat menjadikan dunia sekedar sarana akhirat sehingga ia tidak lupa akan keuntungan pada akhirat. Oleh karena itu, hal ini dapat menjadikan kegiatan usaha di pasar sebagai tempat untuk mengingat Allah SWT.

5. jangan terlalu ambisius dalam urusan berbisnis, Al-Ghazali menyarankan pada para pedagang agar tidak terlalu ambisi (rakus) dalam meraih keuntungan yang besar pada kegiatan bisnis.

6. Kegiatan berbisnis dapat menjauhkan segala kegiatan usaha yang meragukan (syubhat). Sebaiknya ada batasan dalam jual beli tidak hanya sebatas barang yang diharamkan, tetapi pada barang yang meragukan di dalamnya pada kegiatan transaksi jual beli.

7. Dalam kegiatan bisnis senantiasa selalu introspeksi dalam urusan berdagang sewajarnya bagi seorang pedagang dapat meneliti kembali dan mengawasi apa yang terjadi antara penjual dan pembeli dalam kegiatan bertransaksi jual beli hendaklah bersikap baik, agar tidak mengecewakan pihak lain dengan hal-hal di luar batas kebiasaan, bersikap memudahkan perbuatan dalam jual beli yang di anjurkan dalam Islam.

Etika bisnis dalam perilaku pasar Imam AlGhazali adalah suatu kegiatan di dalamnya adanya etika deontologi atau etika religius yang bersumber pada ajaran Islam seperti al-quran, al-hadits, atsar sehingga dapat ditelusuri oleh manusia dari segi kognitif, efektif maupun psikomotorik sehingga dapat melahirkan perilaku etis di pasar dalam bertransaksi bisnis atau jual beli. Dari segi kognitif baik dari produsen maupun konsumen harus mengerti nilainilai keadilan dalam bertransaksi untuk menciptakan pasar yang efektif dan efisiensi. Pada segi efektif baik itu dari produsen dengan memiliki motivasi dan niat yang sesuai ajaran Islam.

\section{Perilaku Pasar Menurut Al-Ghazali}

Perilaku pasar menurut Al-Ghazali merupakan fungsi berdasarkan perilaku, moral pada kegiatan pasar berdasarkan para pelakunya. Namun, beliau mengingatkan dalam kegiatan transaksi bisnis atau berdagang beliau melarang mengambil keuntungan yaitu dengan cara menimbun makanan atau barangbarang kebutuhan lainnya artinya jika menimbun terjadi maka dapat menyebabkan hal yang merugikan. Dalam hal ini, Pandangan Al-Ghazali tentang etika pasar dalam artian kegiatan bisnis harus sesuai dengan caranya dan berjalan dengan cara bebas dan bersih dari bentuk penipuan atau gharar artinya etika bisnis terhadap para pelaku pasar dapat mencerminkan kebajikan yang baik. 


\section{Jurnal Ilmiah Ekonomi Islam, 6(03), 2020, 505}

Bagi imam Al-Ghazali kedudukan pasar merupakan sunatullah atas takdir orang-orang sebagai makhluk sosial, dalam artian manusia tidak dapat hidup sendiri melainkan dengan adanya orang lain. Imam Al-Ghazali menganggap penting kedudukan pasar dalam kehidupan manusia. Namun dalam kapasitasnya beliau sebagai seorang sufi beliau menginginkan manusia tidak lupa pada kedudukannya sebagai makhluk Allah SWT seperti yang terjadi pada masa kehidupannya.

Pandangan al-Ghazali tentang permasalahan moral atau etika dalam perilaku pasar atau perdagangan. Secara khusus al-Ghazali melarang mengambil keuntungan dengan cara menimbun barang-barang. Penimbunan barang merupakan kezaliman yang besar.

Dalam lingkup ekonomi mikro, etika pasar Imam al-Ghazali ditujukan pada pembentukan perilaku yang sesuai dengan ajaran Islam. Pada umumnya perilaku atau aktivitas-aktivitas itu merupakan manifestasi kehidupan psikis yang berupa kebaikan yang bersumber pada al-Qur'an dan al-Hadits itu diinternalisir manusia secara lahir dan batin pada aspek kognitif (pengetahuan), afektif (perasaan) dan psikomotorik (perbuatan) sehingga melahirkan perilaku etis di pasar.

\section{Larangan menimbun uang (Money hoarding)}

Dasar dari pemikiran Al-Ghazali tentang larangan penimbunan uang karena dapat menghilangkan fungsi uang yang melekat pada nilai intrinsik uang. Adapun tujuan adanya uang agar dapat beredar di masyarakat yang dikatakan sebagai kegiatan transaksi, bukan untuk di monopoli oleh para golongan-golongan tertentu saja, dalam hal ini dapat mengakibatkan berdampak buruk dalam kegiatan menimbun uang yang disebut dengan inflasi.

Fungsi dari uang dapat membantu untuk membangun masyarakat agar lebih baik dan maju dalam kegiatan aktivitas ekonomi bisnis. Kegiatan atau aktivitas dari penimbun uang dapat mengakibatkan kemudharatan bagi keberlangsungan aktivitas ekonomi di dalam masyarakat. Setiap orang atau pelaku ekonomi dalam artian melakukan kegiatan penimbunan uang dalam aktivitas ekonomi maka hal tersebut dapat memberikan kemudharatan bagi orang banyak

Teori ekonomi dapat menjelaskan antara jumlah barang yang beredar di pasar dengan jumlah uang yang tersedia dapat mempunyai hubungan erat atau berbanding terbalik. Namun, dapat dikaitkan apabila jumlah uang yang beredar melebihi dari jumlah barang yang tersedia maka hal ini dapat mengakibatkan terjadinya kegiatan dinamakan dengan inflasi. Berbanding sebaliknya, jika jumlah uang beredar lebih sedikit dari pada barang yang tersedia di pasar maka dapat mengakibatkan terjadi suatu kegiatan yang dinamakan dengan deflasi. Dapat diartikan bahwa antara inflasi dan deflasi dapat dikatakan penyakit dari kegiatan ekonomi harus di hindari, dalam artian antara barang yang tersedia di pasar dengan jumlah uang yang beredar harus seimbang di pasar. Al-Ghazali menyatakan bahwa:

"jika seseorang menimbun dirham dan dinar dia telah berdosa besar. Dinar dan dirham selalunya tidak memiliki kegunaan pada dirinya. Dinar dan dirham dicipta supaya ditagihkan dari tangan ke tangan, untuk mengatur dan memudahkan pertukaran, sebagai simbol untuk mengetahui nilai barang dan kelas. Siapa pun yang mengubahnya menjadi peralatan-peralatan emas dan perak biasanya tidak bersyukur kepada penciptanya dan lebih buruk berbanding menimbun uang. Orang yang mengubah emas seolah-olah memaksa pemerintah untuk melakukan apa yang tidak sepatutnya seperti mengenakan cukai. Menimbun uang adalah lebih baik berbanding mengubahnya karena terdapat logam, tembaga, perunggu, besi dan tanah liat yang dapat digunakan untuk membuat (barangan atau perhiasan). Namun, logam lain (Lembaga, tanah dan sebaginya) tidak dapat untuk menggantikan fungsi dijalankan dirham dan dinar".

Menurut al-Ghazali, larangan dari kegiatan menimbun uang dapat terjadi suatu tindakan yang dapat menghilangkan fungsi nilai dari uang tersebut. Al-Ghazali menyatakan bahwa tujuan dari uang dapat wujudkan sebagai alat transaksi atau alat tukar agar dapat beredar dalam masyarakat sehingga tidak dapat dimonopoli oleh para golongan tertentu saja. Akan tetapi, Al-Ghazali memberikan perumpamaan dapat menyatakan bahwa uang seperti seorang hakim yang harus adil dalam memberikan tanggung jawab, memutuskan perkara dalam dalam transaksi. Menimbun uang sendiri dalam artian melanggar pemerintah dapat dikatakan tidak dapat menjalankan kegiatannya dengan benar, tetapi dapat memberikan kezaliman bagi manusia.

\section{Problematika Riba}

Al-Ghazali memberikan alasan tentang problematika pengharaman riba terkait dengan uang pada dasarnya motif di cetaknya uang itu sendiri, 


\section{Jurnal Ilmiah Ekonomi Islam, 6(03), 2020, 506}

yakni sebagai satuan alat tukar menukar dari nilai intrinsik uang tersebut, namun bukan sebagai komoditas yang berupa riba dengan cara tukar menukar uang yang tidak sejenis hal tersebut tindakan yang dilarang dalam agama dan keluar dari tujuan awal penciptaan uang. Pemikiran al-Ghazali tentang problematika riba sangat sesuai, amanat dalam kegiatan ekonomi dalam artian bahwa uang adalah uang, fungsi dari uang merupakan alat tukar menukar dari kegiatan transaksi atau aktivitas ekonomi dan alat penyimpan nilai. Dalam artian uang tidak dapat berkembang biak.

Riba secara sederhana dapat dikatakan sebuah nilai tambahan atas modal pokok dengan keuntungan yang diperoleh dari cara yang batil. Dalam al-quran Surah al-Baqarah ayat 275 dijelaskan:

Orang-orang yang memakan riba [174] tidak dapat berdiri melainkan seperti berdirinya orang yang kemasukan syaitan lantaran (tekanan) penyakit gila [175] keadaan mereka yang demikian itu adalah disebabkan mereka berkata (berpendapat) sesungguhnya jual beli itu sama dengan riba, padahal Allah SWT telah menghalalkan jual beli dan mengharamkan riba. Orang-orang yang telah sampai kepadanya larangan tuhannya, lalu terus berhenti (dari mengambil riba) maka baginya apa yang telah di ambilnya dahulu [176] (sebelum datang larangan) dan urusannya (terserah) kepada Allah SWT, orang yang kembali (mengambil riba), maka orang itu adalah penghuni-penghuni neraka mereka kekal di dalamnya.

\section{Jual Beli Mata Uang}

Al-Ghazali telah melarang melakukan kegiatan jual beli mata uang. Karena jual beli beli mata uang hanya diperbolehkan oleh mereka dalam artian membiarkan mereka melakukan kegiatan penimbunan uang yang terjadi dalam masyarakat. Oleh karena itu diperjualbelikan mata uang merupakan kegiatan yang beredar pada golongan atau kalangan-kalangan orangorang tertentu dalam artian mereka saja, yaitu orangorang kaya. Namun dapat dikatakan dalam tindakan atau kegiatan yang sangat zalim. Al-Ghazali berpendapat bahwa dengan jiwa kemanusiaan yang universal dalam etika bisnis islami. Dapat dikatakan bahwa pemikiran Al-Ghazali tentang keuangan ekonomi yang masih berserakan dapat melakukan kerja keras dari para pewarisnya dalam artian dapat merekonstruksi secara ulang dalam artian sistematis dan logis.
Dalam masalah jual beli mata uang dapat dikatakan sama dengan aktivitas riba yaitu dengan cara memperjualbelikan mata uang dalam aktivitas ekonomi. Al-Ghazali secara jelas menyatakan bahwa melarangkan aktivitas perdagangan jual beli mata uang. Dalam hal ini Al-Ghazali berkata bahwa:

"Bahwa dilarang amalan jual beli mata uang karena jika hal ini diperbolehkan sama saja dengan membiarkan orang orang yang melakukan aktivitas kanz al-mal (penimbunan uang) yang mengakibatkan pada berkurang uang dalam masyarakat. Karena dengan sebab jual beli mata uang. Uang akan berdar pada golongan tertentu yaitu orang kaya yang akan melakukan amalan tersebut (yang melakukan jual beli mata uang) dan ini tidak dapat dinafikan lagi adalah tindakan yang zalim".

Dalam hal ini, al-Ghazali menyatakan bahwa jual beli uang dari barang yang berlainan jenisnya misalnya dinar dengan dirham. Karena keduanya diperbuatkan dari bahan yang berbeda dari segi kualitas dan rupa bentuk. Pertukaran uang yang berbeda sangat diperlukan untuk aktivitas ekonomi. Dalam hadis ini:

"janganlah kalian jual beli emas dengan emas dan perak dan perak kecuali dengan timbangan yang setara. Dan jadilah emas dengan perak dan perak dengan emas mengikut kehendak kalian (H.R alBukhari).

\section{KESIMPULAN}

Dari kesimpulan di atas dapat di tarik beberapa hal mengenai etika bisnis dan perilaku pasar ekonomi Al-Ghazali meluruskan niat, melaksanakan fardhu kifayah, memperhatikan pasar akhirat, terus berzikir ketika berada di pasar, jangan terlalu ambisius dalam berbisnis, menjauhkan dari segala hal yang meragukan dan introspeksi dalam hal berdagang. Sedangkan dalam hal perilaku pasar adanya penimbunan uang, problematika riba artinya adanya jual beli mata uang.

Sehingga zaman sekarang, pemikiran ekonomi Al-Ghazali tentang penimbunan uang pada konteks sekarang ini, terjadi praktik penimbun dolar untuk spekulasi, sehingga masyarakat terus menunggu kurs yang lebih tinggi, maka dolar menjadi langka. Adanya problematika riba masih terjadi dalam masyarakat sekarang ini setiap penambahan yang dilakukan dalam transaksi jual beli antara produsen maupun konsumen dalam perekonomian dikatakan dengan riba dan tentang jual beli mata uang masih terjadi dengan 
istilah valas dalam perekonomian. Naik turun kurs mata uang dalam perekonomian negara, sehingga muncul persaingan yang tidak sehat antara pelaku bisnis sehingga timbulnya spekulasi yang mengakibatkan risiko tinggi.

\section{UCAPAN TERIMA KASIH}

Ucapan terima kasih penulis sampaikan kepada semua pihak yang telah berkontribusi dalam penelitian ini, serta telah memberikan bimbingan dan arahan untuk penulis hingga penelitian ini dapat diselesaikan.

\section{DAFTAR PUSTAKA}

Al-Ghazali, I. (2014). Ringkasan Ihya Ulumuddin, Bandung, Sinar Baru Algensindo

Amalia Euis. (2010). No Title. In Sejarah Pemikiran Ekonomi Islam dari Masa Klasik hingga Masa Kontemprer.

Azwar, K. A. (2017) Sejarah Pemikiran Ekonomi Islam Depok, cet 8, PT Raja Grafindo Persada

Fahlefi, R. (2012). Pemikiran Ekonomi Al-Ghazali Oleh: Rizal Fahlefi*. JURIS, 11 No $1 \mathrm{Ju}, 11$

Faizal, M. (2015). Studi Pemikiran Imam Al-Ghazali Tentang Ekonomi Islam. Islamic Banking, 1(1), 49-58.

Hasan, F. A. Al. (2014). Etika Bisnis. 01(01 April), 16.
Muhammad. (2019). Sejarah Pemikiran Ekonomi Islam Yogyakarta, UII Press

Mohamed Yusof, M. F., Borhan, J. T., \& Romli, N. (2016). Pemikiran Ekonomi Al-Ghazali Dalam Teori Kewangan. UMRAN - International Journal of Islamic and Civilizational Studies (EISSN: 2289-8204), 3(3), 79-95.

Nur, C. (2010). Jejak Langkah Sejarah Pemikiran Ekonomi Islam. Yogyakarta, cet 1 Pustaka Pelajar

Personal, M., \& Archive, R. (2018). Munich Personal RePEc Archive Theory of exchange and the evolution of markets perspective of Al-Ghazali. 87292.

Sopingi Imam. Iqtishoduna Jurnal Ekonomi Dan Bisnis Islam.

Suprihatin, Suprihatin. Ibdalsyah, H. T. (2018). Analisis Pemikiran Imam Al-Ghazali Mengenai Mekanisme. Islamic Economy, 7308(1), 42-57

Uang.co.id, https://m. republika. spekulas. dalam penimbunan.

(Www.https://m.bisnis.com, n.d.)

Yadi, J. (2016). Pemikiran Ekonomi Islam dari Masa Rasulullah Hingga Masa Kontemporer (Bandung, cet.1 PT Remaja Rosdakarya 